\title{
Melting experiments of kimberlite compositions up to 9 GPa: Determination of melt compositions using aggregates of diamond grains
}

\author{
Yamashita, H. ${ }^{1}$, Arima, M. ${ }^{2}$, and Ohtani, E. ${ }^{3}$
}

1. Kanagawa Prefectural Museum of Natural History, Odawara, Kanagawa 250, Japan.

2. Yokohama National Univ., Tokiwadai, Hodogaya-ku, Yokohama 240, Japan.

Core Research for Evolutional Science and Technology (CREST), Japan Sccience and Technology Corporation (JST)

3. Tohoku Univ., Aramaki, Aoba-ku, Sendai 980, Japan.

\section{Introduction}

Navon et al. (1988) and Schrauder and Navon (1994) reported mantle derived fluid compositions from diamond inclusions. Compositions of mantle fluids are characterized by high abundance of $\mathrm{H}_{2} \mathrm{O}, \mathrm{CO}_{2}$, $\mathrm{K}_{2} \mathrm{O}$ and $\mathrm{LREE}$ and depletion of $\mathrm{MgO}$, those are broadly similar to group II kimberlite and lamproite compositions. These mantle fluids might play important roles in generation of kimberlite, lamproite and carbonatite magmas. In this paper, we report the melting phase relationships of aphanitic group II kimberlite composition up to $9 \mathrm{GPa}$ and melt compositions determined using aggregates of diamond grains at $7 \mathrm{GPa}$.

\section{Melting experiment of aphanitic group II kimberlite}

Melting phase relations of aphanitic group II kimberlite have been studied in the pressure up to $9 \mathrm{GPa}$. The starting composition chosen for this study is group II aphanitic kimberlite (173/24/K19/57) from Makganyene Mine, South Africa. This composition is characterized by higher $\mathrm{SiO}_{2}, \mathrm{~K}_{2} \mathrm{O}, \mathrm{Al}_{2} \mathrm{O}_{3}$ and $\mathrm{Ba}$ than the average group I kimberlite composition (Shee et al., 1989). $\mathrm{X}_{\mathrm{CO} 2}\left(\mathrm{CO}_{2} /\left(\mathrm{CO}_{2}+\mathrm{H}_{2} \mathrm{O}\right)\right.$ ratio) is 0.59 . A multi-anvil high pressure apparatus at Tohoku University and a $1 / 2$ inch diameter pistoncylinder apparatus at Yokohama National University were used for the experiments above $4 \mathrm{GPa}$ and below $3 \mathrm{GPa}$ respectively. All experiments were carried out with a sealed Pt sample capsule, a Pt/ PtRh13 thermocouple and graphite heater.

The liquidus temperature is determined about $1470^{\circ} \mathrm{C}$ at $6 \mathrm{GPa}$ and $1520^{\circ} \mathrm{C}$ at $8 \mathrm{GPa}(\mathrm{Fig}$. 1). Suprasolidus phase assemblage at $1400^{\circ} \mathrm{C}$ varies with elevating pressure as; $\mathrm{Phl}+\mathrm{Liq}, \mathrm{Phl}+\mathrm{Cpx}+$ $\mathrm{Liq}, \mathrm{Phl}+\mathrm{Cpx}+\mathrm{Opx}+\mathrm{Liq}, \mathrm{Cpx}+\mathrm{Opx}+\mathrm{Gt}+\mathrm{Liq}, \mathrm{Cpx}+\mathrm{Gt}+\mathrm{Liq}$. Phlogopite breakdowns between $1300-1400^{\circ} \mathrm{C}$ and 6-7 GPa by the reaction $\mathrm{Phl}+\mathrm{Cpx}=\mathrm{Gt}+$ Liq. Phlogopite is not a stable phase above 6-7 $\mathrm{GPa}$ at $1300-1400^{\circ} \mathrm{C}$. Neither stable K-bearing, hydrate-, nor carbonate-crystalline phase were observed in the run products above $7 \mathrm{GPa}$. The data suggest that the aphanitic group II kimberlite magma can be equilibrated with eclogitic assemblage above $6.5 \mathrm{GPa}$, with phlogopite-peridotitic assemblage at $6.5-7 \mathrm{GPa}$ at $900^{\circ} \mathrm{C}$.

\section{Determination of melt composition}

Melt compositions in the run products at relatively low temperatures are multiply saturated with silicate phases. Low abundances of these melt phases in the run products hamper the precise determination of their composition using microprobe analyses. In this study, an attempt was made to separate melt formed by partial melting of kimberlite into pore space between diamond grains at high pressures. Diamond powder ( $3 \mu \mathrm{m}$ in diameter) was packed on top of tightly packed kimberlite powder (the ratio of diamond to kimberlite is 1:2). In the selected run, the charges were loaded in graphite capsules. The graphite capsule, then loaded in sealed Pt capsules.

Melt compositions in the run products at $7 \mathrm{GPa}$ were determined by analyzing melt phase trapped in interstitial area between diamond grain (Table 1). The melts analyzed are in equilibrium with $\mathrm{Ol}+$ $\mathrm{Opx}+\mathrm{Cpx}+\mathrm{Phl}$ (phlogopite) $+\mathrm{Ap}$ (apatite) at $900^{\circ} \mathrm{C}$, and $\mathrm{Opx}+\mathrm{Cpx}+\mathrm{Gt}$ above $1100^{\circ} \mathrm{C}$ (Fig. 1). Run products were polished by diamond powder without a water and analyzed with a scanning 
microprobe (JEOL-JSM-5300) with Link EDS system. Analytical conditions were $15 \mathrm{KV}$ accelerating voltage and $120 \times 90 \mu \mathrm{m}$ spot area.

\section{Chemical characteristic of melt}

Melts in the runs at $7 \mathrm{GPa}$ are extremely enriched in $\mathrm{K}_{2} \mathrm{O}, \mathrm{H}_{2} \mathrm{O}$ and $\mathrm{CO}_{2}$ and depleted in $\mathrm{SiO}_{2}$ (Table. 1). The analyses indicate that $\mathrm{SiO}_{2}$ and $\mathrm{Al}_{2} \mathrm{O}_{3}$ in melts decrease with decreasing temperature, while $\mathrm{K}_{2} \mathrm{O}$ in melts increases with decreasing temperature. No $\mathrm{P}_{2} \mathrm{O}_{5}$-bearing crystalline phase exists in the run products above $1100^{\circ} \mathrm{C}$ but in the run at $900^{\circ} \mathrm{C}$ apatite is a stable phase. Based on mass balance calculation, we estimate proportion of melt in each run product and $\mathrm{H}_{2} \mathrm{O}$ and $\mathrm{CO}_{2}$ contents in the melts at various temperatures (Table 1).

Composition of melts in this study are broadly similar to those reported from diamond inclusions by Navon et al. (1988) and Schrauder and Navon (1994)(Fig. 2). It is noted that dolomitic melt (Mg/ $(\mathrm{Mg}+\mathrm{Ca})=0.52)$ coexists with a phlogopite-bearing peridotitic assemblage at $900^{\circ} \mathrm{C}$ and $7 \mathrm{GPa}$. This result is consistent with recent melting experimental results in the magnesite-diopside system (Arima and Presnall, 1995), and those in the $\mathrm{CMASCO}_{2}$ system from 3.0-7.0 GPa (Dalton and Presnall, 1998). Melts enriched in $\mathrm{CO}_{2}, \mathrm{~K}_{2} \mathrm{O}$, and $\mathrm{H}_{2} \mathrm{O}$ might account for kimberlite- and lamproite-magma genesis, diamond growth in subcratonic mantle, and mantle metasomatism near asthenosphere-lithosphere boundary.

\section{Reference}

Navon, O., Hutcheon, D., Rossman, G. R., and Wasserburg, G. J., 1988, Mantle-derived fluids in diamond micro-inclusions: Nature, 335, p. 784-789.

Schrauder, D., and Navon, O., 1994, Hydrous and carbonatitic mantle fluids in fibrous diamonds from Jwaneng, Botwana: Geochim. Cosmochim. Acta., 58, p. 761-771.

Yamashita, H., and Ohtani, E., 1995, High pressure and high temperature experimants of group II kimberlite at $7 \mathrm{GPa}$ : Compositions of volatile-rich melts in the upper mantle (in Japanese): Bull. Kanagawa prefect. Mus. (Nat. Sci.), 24, p. 1-8.

Table 1. Chemical compositions of aphanitic group II kimberlite and melts formed by partial melting

\begin{tabular}{lrrrrr}
\hline & \multicolumn{1}{c}{1} & \multicolumn{1}{c}{2} & \multicolumn{1}{c}{3} & \multicolumn{1}{c}{4} & \multicolumn{1}{c}{5} \\
\hline $\mathrm{SiO} 2$ & 40.90 & 3.34 & 9.08 & 28.79 & 36.17 \\
$\mathrm{TiO} 2$ & 1.00 & 0.17 & 2.24 & 2.21 & 1.22 \\
$\mathrm{Al} 2 \mathrm{O} 3$ & 5.28 & 1.05 & 0.89 & 2.74 & 4.88 \\
$\mathrm{FeO}$ & 8.43 & 4.57 & 4.44 & 2.39 & 6.72 \\
$\mathrm{MnO}$ & 0.24 & 0.17 & 0.00 & 0.00 & 0.00 \\
$\mathrm{MgO}$ & 18.44 & 7.77 & 10.93 & 14.69 & 13.31 \\
$\mathrm{CaO}$ & 9.37 & 9.88 & 7.05 & 8.70 & 6.89 \\
$\mathrm{Na} 2 \mathrm{O}$ & 1.22 & 3.16 & 1.94 & 0.71 & 1.26 \\
$\mathrm{~K} 2 \mathrm{O}$ & 5.92 & 28.09 & 29.16 & 11.15 & 9.34 \\
$\mathrm{P} 2 \mathrm{O} 5$ & 1.09 & 0.40 & 3.79 & 3.11 & 2.26 \\
$\mathrm{BaO}$ & & 0.40 & 0.40 & 0.82 & ---- \\
$\mathrm{CO} 2 *$ & 6.70 & 31.79 & 23.33 & 19.14 & 13.92 \\
$\mathrm{H} 2 \mathrm{O} *$ & 1.94 & 9.21 & 6.75 & 5.54 & 4.03 \\
& & & & & \\
total & 100.53 & 100 & 100 & 100 & 100 \\
\hline
\end{tabular}

1. Aphanitic group II kimberlite used as starting material.

2. $100 \%$ normalized melt formed at $900{ }^{\circ} \mathrm{C}$ (Apdia-13**)

3. $100 \%$ normalized melt formed at $1100{ }^{\circ} \mathrm{C}$ (Apdia-9**)

4. $100 \%$ normalized melt formed at $1300{ }^{\circ} \mathrm{C}$ (Apdia-1)

5. $100 \%$ normalized melt formed at $13500^{\circ} \mathrm{C}$ (Apdia- ${ }^{* *}$ )

* $\mathrm{CO} 2$ and $\mathrm{H} 2 \mathrm{O}$ caiculated by $\mathrm{K} 2 \mathrm{O}$ or $\mathrm{P} 2 \mathrm{O} 5$

** 2, 3 and 5 wert used Pt and graphite double capsule 


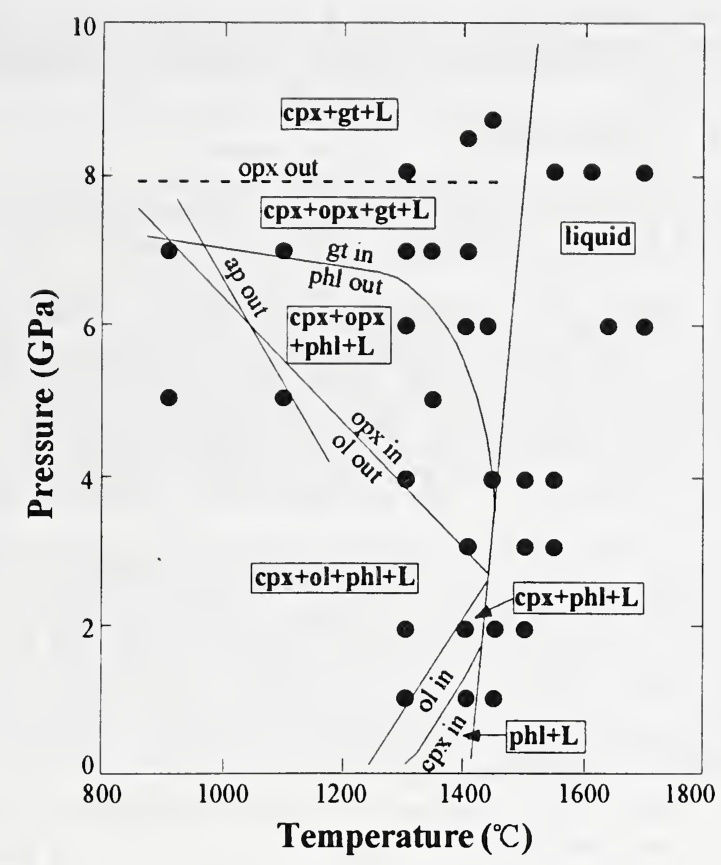

Fig.1 Phase diagrum of aphanitic group II kimberlite

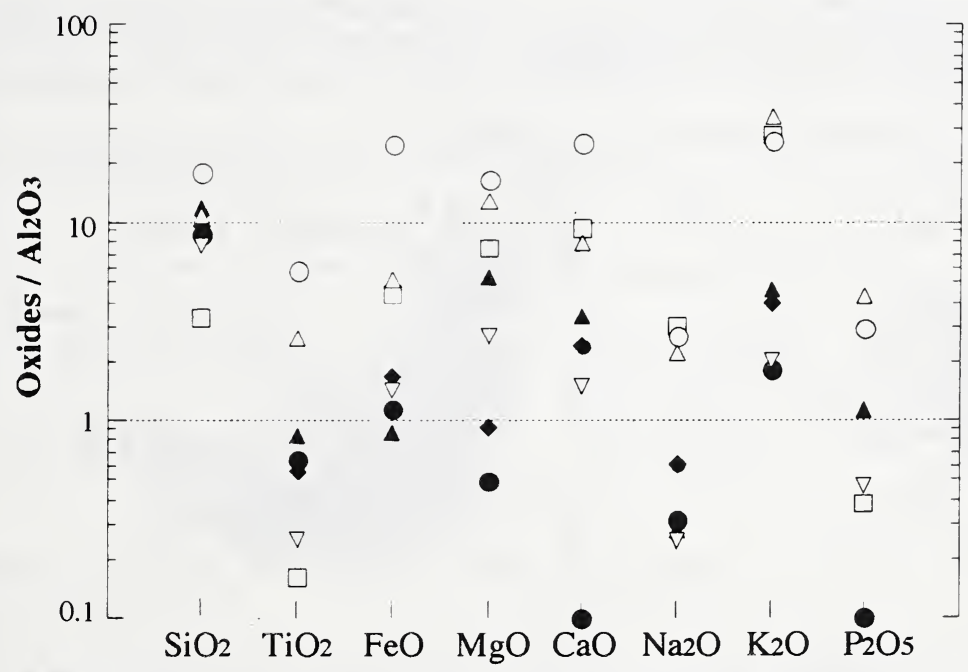

- Compositional endmember of hydrous fluid in Botswanan diamond (Schrauder and Navon, 1994)

- Compositional endmember of carbonatitic fluid in Botswanan diamond (Schrauder and Navon, 1994)

- Average composition of diamond inclusion fluid (Navon at al., 1988)

口 Apdia-13 $\left(900^{\circ} \mathrm{C}\right)$

$\Delta$ Apdia-9 $\left(1100^{\circ} \mathrm{C}\right)$

$\triangle \operatorname{Apdia}-1\left(1300^{\circ} \mathrm{C}\right)$

$\boldsymbol{\nabla} \operatorname{Apdia}-7\left(1350^{\circ} \mathrm{C}\right)$

Fig. 2 Oxides/ $\mathrm{Al}_{2} \mathrm{O} 3$ ration in the melts. 